\title{
ANALISIS KEMAMPUAN SELF HEALING PADA LAPIS ASPAL BETON DENGAN LIMBAH BUBUTAN BAJA SEBAGAI BAHAN TAMBAH
}

\author{
Alida Danar Saputra ${ }^{1}$ dan Anissa Noor Tajudin ${ }^{2}$ \\ ${ }^{1}$ Program Studi Sarjana Teknik Sipil, Universitas Tarumanagara, Jl. Letjen S. Parman No.1 Jakarta \\ alidas.ts@stu.untar.ac.id \\ ${ }^{2}$ Program Studi Sarjana Teknik Sipil, Universitas Tarumanagara, Jl. Letjen S. Parman No.1 Jakarta \\ anissat@ft.untar.ac.id
}

Masuk: 16-01-2021, revisi: 22-02-2021, diterima untuk diterbitkan: 30-11-2021

\begin{abstract}
Steel waste is waste generated from a large or small amount of steel production process. The results of steel waste disposal can pollute the environment if not done a good treatment and countermeasure so that it has value benefits. This study uses steel lathe waste additives to determine the self-healing ability of asphalt in the AC-WC mixture. Steel lathe waste used with varying degrees of steel lathe 0\%, 0,25\%,0,5\%,0,75\%, 1\% and asphalt content used by 5,5\%. After obtaining the data used in the study, samples were made for asphalt mixtures with varying degrees. Then the finished sample is divided into 4 parts to be tested for temperature rise on each steel lathe mixture using a thermal camera. And tested using a threepoint bending test to determine the ability of asphalt selfhealing in the AC-WC mixture that occurs for 5 cycles with a heating duration of 20 seconds, 40 seconds, 60 seconds. From the results of the research on the content of a mixture of $0 \%$ steel lathe proved the sample can do self-healing but the results obtained are not as good as when using variations in the added ingredients of steel fiber mixture 0,25\%, 0,5\%,0,75\% and $1 \%$.
\end{abstract}

Keywords : AC-WC; Steel Waste; Self Healing; Temperature Characteristics; Healing Ratio.

\begin{abstract}
ABSTRAK
Limbah baja adalah buangan yang dihasilkan dari suatu proses produksi baja baik dalam jumlah yang besar atau sedikit. Hasil buangan limbah baja dapat mecemari lingkungan apabila tidak dilakukan pengolahan dan penanggulangan yang baik sehingga memiliki nilai manfaat. Penelitian ini menggunakan bahan tambahan limbah bubutan baja untuk dapat mengetahui kemampuan self healing aspal pada campuran AC-WC. Limbah bubutan baja yang digunakan dengan kadar variasi bubutan baja 0\%, 0,25\%, 0,5\%, 0,75\%, $1 \%$ dan kadar aspal yang dipakai sebesar $5,5 \%$. Setelah didapatkan data yang dipakai dalam penelitian dilakukan pembuatan sampel terhadap campuran aspal dengan variasi kadar. Kemudian sampel yang telah jadi di belah menjadi 4 bagian untuk diuji kenaikan temperatur pada setiap campuran bubutan baja dengan menggunakan kamera thermal. Serta diuji dengan menggunakan alat threepoint bending test untuk mengetahui kemampuan selfhealing aspal pada campuran AC-WC yang terjadi selama 5 siklus dengan durasi pemanasan 20 detik, 40 detik, 60 detik. Dari hasil penelitian pada kadar campuran bubutan baja $0 \%$ terbukti sampel dapat melakukan self healing tetapi hasil yang didapatkan tidak sebaik ketika menggunakan variasi bahan tambah campuran serat baja $0,25 \%, 0,5 \%, 0,75 \%$ dan $1 \%$.
\end{abstract}

Kata kunci : AC-WC; Limbah Baja; Self Healing; Karakteristik Temperatur; Rasio Healing.

\section{PENDAHULUAN}

Berlebihnya beban roda kendaraan yang melintas seiring berjalannya waktu dapat menyebabkan lapisan perkerasan jalan mengalami keretakan. Keretakan ini menyebabkan air pada permukaan perkerasan masuk ke lapisan jalan yang akan membuat semakin parah suatu kerusakan. Kerusakan yang terjadi tidak hanya pada permukaan jalan saja tetapi bisa menyebabkan kerusakan deformasi dan kerusakan tekstur permukaan jalan. Banyaknya kerusakan-kerusakan yang terjadi dapat diperbaiki salah satunya dengan cara metode self-healing aspal.

Metode self-healing aspal sendiri sudah banyak dikembangkan di negara-negara maju. Salah satu contoh metode yang pernah dikembangkan adalah dengan pemanasan gelombang mikro (mikrowave). Di Indonesia sendiri penelitian 
dengan metode ini masih jarang dilakukan karena proses dan mengaplikasikannya yang cukup sulit. Aspal secara natural dapat memulihkan diri sendiri, namun proses ini akan memakan waktu jika terjadi pada termperatur ruangan, sehingga diperlukan bahan yang dapat menghantarkan konduktor panas untuk mempercepat proses pemanasan aspal, salah satunya dengan besi atau baja. Dalam penelitian ini, digunakan konduktor berupa limbah bubutan baja. Diharapkan penggunaan limbah bubutan baja dengan pemanasan metode mikrowave dapat membuat peningkatan suhu panas yang dihasilkan akan lebih merata sehingga proses self-healing yang terjadi akan lebih baik.

Berdasarkan latar belakang tersebut, tujuan dari penelitian ini adalah untuk menganalisis pengaruh variasi kadar limbah bubutan baja dan durasi pemanasan terhadap kemampuan self-healing campuran lapis aspal beton (AC - WC).

\section{Penggunaan limbah pada perkerasan}

Berdasarkan PP Nomor 18 Tahun 1999, limbah merupakan sisa/buangan dari suatu usaha dan atau kegiatan manusia (Pemerintah Republik Indonesia, 1999). Hampir semua kegiatan manusia akan menghasilkan limbah yang beragam jenisnya, mulai dari limbah rumah tangga, komunal, atau limbah industri. Limbah tersebut sering kali berakhir ke lingkungan. Lahan yang tersedia semakin sempit sementara jumlah limbah yang dihasilkan terus meningkat seiring dengan pertambahan penduduk dan kemajuan teknologi. Dalam bidang transportasi, sudah terdapat banyak penelitian dan implementasi pemanfaatan limbah, terutama untuk struktur perkerasan, seperti limbah plastik plastik sebagai pengganti agregat, limbah minyak sebagai peremaja aspal, dan limbah metal sebagai perantara panas dalam perkerasan yang dirancang dapat memulihkan diri sendiri (Tajudin \& Suparma, 2017; Cao, et al., 2018; Li, et al., 2019; González, Norambuena-Contreras, Storey, \& Schlangen, 2018).

Limbah bubutan baja memiliki bentuk yang tidak beraturan dengan lebar lebih besar dari serat baja biasa yang digunakan untuk tujuan self-healing aspal. Tujuan dari penambahan limbah bubutan baja adalah meningkatkan penyembuhan retak campuran aspal, dengan cara meningkatkan suhu rata-rata permukaan sampel aspal setelah pemanasan gelombang mikro lebih tinggi dari pada suhu yang diperoleh dengan pemanasan induksi. Sifat-sifat dari penambahan limbah baja terhadap perkerasan, diantaranya : Perubahan viskositas, modulus dinamis, dan rutting (Garc'1a, Norambuena-Contreras, Bueno, \& Partl, 2014; Ajam, Gómez-Meijide, Artamendi, \& Garcia, 2018).

\section{Kemampuan self-healing pada aspal}

Self-healing asphalt adalah aspal yang dapat memperbaiki sendiri kerusakan retak (crack) dan pelepasan butiran (ravelling) yang terjadi di dalam lapis permukaan jalan. Menurut White dkk (2001), Self-Healing sendiri dapat didefinisikan sebagai kemampuan bawaan dari suatu material secara otomatis menyembuhkan (memperbaiki) kerusakan yang terjadi selama masa kerjanya (White, et al., 2001).

Ketika celah mikro pada jalan aspal terbuka bitumen mengalir diantara agregat menuju bagian retak yang sangat kecil, dan dalam kurun waktu tertentu (hari atau minggu) lebar retak tidak bertambah walaupun jalan dilalui kendaran terus menerus maka tingkat penyembuhan diri aspal dipengaruhi oleh viskositas dan komposisi kima bitumen.

\section{Pemanasan perkerasan untuk proses self healing}

Untuk meningkatkan kemampuan penyembuhan campuran aspal, berbagai metode pemanasan dilakukan, antara lain metode pemanasan dengan induksi dan microwave.

Penambahan (serat baja dan wol baja) yang ditambahkan ke lapisan aspal beton berfungsi untuk meningkatkan konduktivitas listriknya serta pemanasan induksi digunakan untuk meningkatkan suhu secara lokal, yang hannya cukup untuk meningkatkan penyembuhan beton aspal pada celah-celah mikro dan memperbaiki ikatan yang terjadi antara agregat dan pengikat. Dan ditemukan bahwa serat panjang dengan diameter kecil lebih baik dari pada serat pendek dengan diameter lebih besar untuk membuat beton aspal menghantarkan panas dengan baik (Garcia, Schlangen, \& Van de Ven, 2009).

Pemanasan mikrowave dengan cara memanfaatkan radiasi gelombang mikro yaitu, gelombang elektromagnetik dengan frekuensi super tinggi yang berada di atas $3 \mathrm{GHz}$ Jika gelombang mikro diserap oleh sebuah benda, akan muncul efek pemanasan pada benda tersebut. Jika didalamnya terdapat benda yang mudah meleleh dan benda tersebut menyerap radiasi gelombang mikro, benda menjadi panas dan meleleh dalam waktu singkat. Pemanasan dengan menggunakan gelombang mikro pada proses self-healing aspal juga memerlukan bahan konduktor sebagai pemanasnya, seperti menggunakan bahan limbah bubutan baja, limbah bubutan baja sendiri merupakan bahan yang mudah meleleh. Penggunaan dengan metode mikrowave membuat peningkatan suhu panas yang dihasilkan akan lebih merata sehingga proses self-healing yang terjadi akan lebih baik dibandingkan dengan metode pemanasan induksi (Liu, Chen, Li, Sun, \& Li, 2018; Pérez, et al., 2016; Sun, Liu, Wu, \& Shang, 2014) 


\section{METODE PENELITIAN}

\section{Metode pembuatan benda uji}

Berikut ini adalah cara pembuatan benda uji untuk pengujian self-healing:

1. Bubutan baja dimaksukkan kedalam campuran aspal tanpa mengganti komposisi agregat atau mengubah kadar aspal. Jumlah bubutan baja yang digunakan bervariasi sebesar $0,25 \% ; 0,5 \% ; 0,75 \% ; 1 \%$ dari berat total agregat (1200 gram) dengan kadar aspal 5,5\% untuk semua campuran.

2. Material kemudian dipanaskan selama 2 jam kemudian dicampur hingga mencapai suhu pencampuran.

3. Kemudian dua jenis sampel dibuat: (i) Sampel silinder dengan ukuran diameter $100 \mathrm{~mm}$ dan tinggi sampel $75 \mathrm{~mm}$ yang telah dipadatkan sebanyak $75 \mathrm{x}$ dengan marshall hammer pada tiap sisi sampel (ii) sampel semi silinder yang didapat dari pemotongan sampel silinder akan menghasilkan 4 sampel semi-silinder dengan ukuran tinggi $5 \mathrm{~cm}$, panjang $10 \mathrm{~cm}$, lebar $3 \pm 0,3 \mathrm{~cm}$

\section{Metode pengujian kemampuan self healing}

Untuk membuktikan bahwa campuran aspal dengan dan tanpa bubutan baja dapat dipanaskan dengan radiasi microwave sampel silinder dibelah menjadi dua untuk dipanaskan dengan microwave pada 3 durasi pemanasan (20 detik, 40 detik, 60 detik).

Pengujian Self-healing dengan microwave dilakukan berdasarkan metode sebagai berikut :

1. Semua sampel diberi kode sesuai dengan kadar Bubutan Baja.

2. Sampel kemudian disimpan pada suhu $-20^{\circ} \mathrm{C} \pm 2^{\circ} \mathrm{C}$ (untuk menghasilkan crack yang seragam).

3. Sampel kemudian dibelah menjadi dua dengan alat three point bending test. Beban ultimate yang terjadi saat sampel terbelah dicatat sebagai $\mathrm{F}_{0}$.

4. Sampel yang telah terbelah disimpan dalam suhu ruangan selama 2 jam kemudian kedua sisinya digabungkan kemudian di panaskan dengan durasi tertentu (20 detik, 40 detik, 60 detik) menggunkana microwave.

5. Kemudian diulangi dari langkah ke dua sampai 5 kali siklus.

6. Beban ultimate yang terjadi pada siklus yang terakhir dicatat sebagai $F_{a}$.

7. Healing ratio dari sampel $\left(\mathrm{S}_{\mathrm{h}}\right)$ didapatkan dengan Persamaan 1 .

$$
\mathrm{Sh}=\frac{\mathrm{Fa}}{\mathrm{Fo}}
$$

dengan $\mathrm{Sh}=$ Healing ratio, $\mathrm{F}_{\mathrm{a}}=$ Beban ultimate akhir, $\mathrm{F}_{0}=$ Beban ultimate awal

\section{HASIL DAN PEMBAHASAN}

Hasil data karakteristik temperatur diperoleh menggunakan kamera thermal dengan variasi kadar tambah bubutan baja $0 \%, 0,25 \%, 0,5 \%, 0,75 \%, 1 \%$ dan waktu pemanasan didalam mikrowave selama 20 detik, 40 detik, 60 detik. Pemanasan dapat dilihat pada 5 titik yang ditinjau dalam pengujian di laboratorium (Gambar 1) dan hasil karakteristik temperatur dapat dilihat pada Tabel 1.

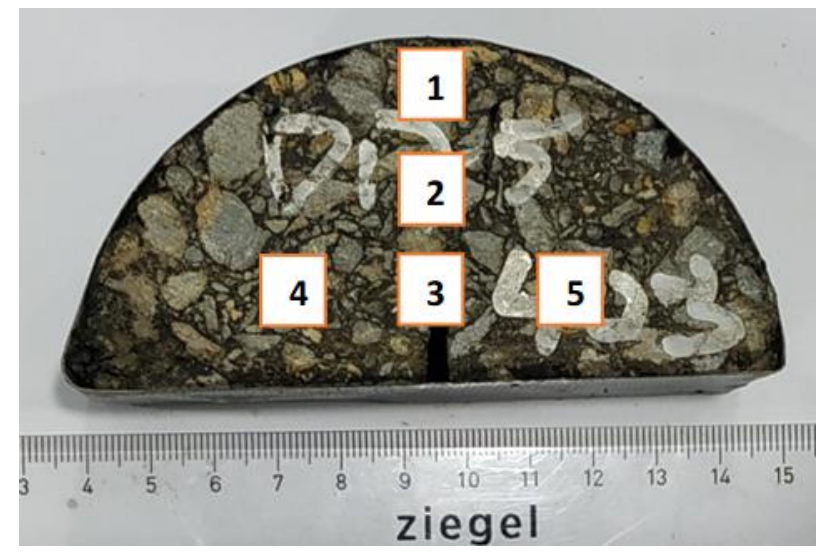

Gambar 1. Lokasi titik penembakan kamera thermal 
Tabel 1. Hasil kecepatan penurunan suhu

\begin{tabular}{|c|c|c|c|c|c|}
\hline \multirow{2}{*}{$\begin{array}{l}\text { Kadar } \\
\text { Sampel }\end{array}$} & \multirow{2}{*}{$\begin{array}{c}\text { Durasi } \\
\text { Pemanasan }\end{array}$} & \multirow{2}{*}{$\begin{array}{l}\text { Suhu } \\
\text { Awal }\end{array}$} & \multirow{2}{*}{$\begin{array}{l}\text { Suhu } \\
\text { Akhir }\end{array}$} & \multirow{2}{*}{$\begin{array}{l}\text { Lama Waktu } \\
\text { (Menit) }\end{array}$} & \multirow{2}{*}{$\begin{array}{c}\text { Penurunan } \\
\text { Suhu/menit } \\
{ }^{\circ} \mathrm{C} / \mathrm{min}\end{array}$} \\
\hline & & & & & \\
\hline \multirow{3}{*}{$0 \%$} & 20 detik & 55,4 & 25 & 46 & 0,660869565 \\
\hline & 40 detik & 82,8 & 25 & 53 & 1,090566038 \\
\hline & 60 detik & 93,8 & 25 & 60 & 1,146666667 \\
\hline \multirow{3}{*}{$0,25 \%$} & 20 detik & 56,6 & 25 & 58 & 0,544827586 \\
\hline & 40 detik & 83 & 25 & 85 & 0,682352941 \\
\hline & 60 detik & 100,6 & 25 & 94 & 0,804255319 \\
\hline \multirow{3}{*}{$0,50 \%$} & 20 detik & 59,6 & 25 & 66 & 0,524242424 \\
\hline & 40 detik & 83,4 & 25 & 91 & 0,641758242 \\
\hline & 60 detik & 102 & 25 & 104 & 0,740384615 \\
\hline \multirow{3}{*}{$0,75 \%$} & 20 detik & 62,6 & 25 & 68 & 0,552941176 \\
\hline & 40 detik & 85,4 & 25 & 94 & 0,642553191 \\
\hline & 60 detik & 105 & 25 & 115 & 0,695652174 \\
\hline \multirow{3}{*}{$1 \%$} & 20 detik & 61,8 & 25 & 70 & 0,525714286 \\
\hline & 40 detik & 84,2 & 25 & 96 & 0,616666667 \\
\hline & 60 detik & 102,2 & 25 & 117 & 0,65982906 \\
\hline
\end{tabular}

Berdasarkan hasil pengujian penurunan suhu setiap menitnya yang sudah dilakukan pada kadar bubutan baja tambahan $0 \%, 0,25 \%, 0,5 \%, 0,75 \%$, dan 1\% dengan waktu pemanasan 20 detik, 40 detik, 60 detik untuk melihat perbandingan penurunan suhu yang diakibatkan perpindahan kalor, semakin tinggi waktu pemanasan yang dilakukan maka semakin tinggi dan sesuai nilai laju kalor yang terjadi.

Perpindahan ini tidak diikuti dengan perpindahan partikel perantara. Berdasarkan kemampuan menghantar kalor, zat dibagi menjadi dua golongan besar, yaitu konduktor dan isolator. Konduktor merupakan zat yang mudah menghantar kalor. Sedangkan Isolator merupakan zat yang tidak mudah menghantar kalor. Banyaknya kalor (Q) yang melalui dinding selama selang waktu t, dinyatakan dari sampel $(\mathrm{H})$ didapatkan dengan Persamaan 2 dan (Q) didapatkan dengan Persamaan 3.

$$
\begin{aligned}
& \mathrm{H}=\frac{\mathrm{Q}}{t}=\frac{\mathrm{k} \cdot \mathrm{A} \cdot \Delta \mathrm{T}}{L} \\
& \mathrm{Q}=k \cdot A \cdot t \frac{\Delta \mathrm{T}}{L}
\end{aligned}
$$

dengan $\mathrm{Q}=\operatorname{kalor}(\mathrm{J})$ atau $(\mathrm{kal}), \mathrm{k}=$ konduktivitas termal $(\mathrm{W} / \mathrm{mK}), \mathrm{A}=$ luas penampang $\left(\mathrm{m}^{2}\right), \Delta \mathrm{T}=$ perubahan suhu $(\mathrm{K}), \mathrm{L} \quad=$ panjang $(\mathrm{m}), \mathrm{H}=$ kalor yang merambat persatuan waktu ( $\mathrm{J} / \mathrm{s}$ atau watt $), \mathrm{t} \quad$ = waktu (sekon)

Besarnya temperatur cenderung meningkat pada variasi kadar campuran bubutan baja 0\%, 0,25\%, 0,5\%, 0,75\%, $1 \%$ dengan peningkatan durasi pemanasan selama 20 detik, 40 detik, dan 60 detik. Sampel dengan waktu pemanasan 60 detik mendapatkan temperatur tertinggi, dilanjutkan dengan sampel dengan waktu pemanasan 40 detik dan 20 detik.

Dapat dilihat temperatur tertinggi terjadi pada campuran bubutan baja $0.75 \%$, diikuti oleh campuran bubutan baja $1 \%$, $0.5 \%, 0.25 \%$ dan $0 \%$ dengan urutannya suhu mencapai $\left(105^{\circ} \mathrm{C}, 102.2^{\circ} \mathrm{C}, 102^{\circ} \mathrm{C}, 100.6^{\circ} \mathrm{C}\right.$, dan $\left.93.8^{\circ} \mathrm{C}\right)$. Dengan kenaikan rata-rata pada setiap durasi 20 detik, 40 detik, dan 60 detik adalah $2,5^{\circ} \mathrm{C}, 0,8^{\circ} \mathrm{C}$, dan $3,7^{\circ} \mathrm{C}$, Pada variasi kadar campuran bubutan baja $0,75 \%$ dengan $1 \%$ terjadi penurunan suhu disebabkan karena tidak merata pendistribusiannya yang terjadi pada kadar $1 \%$ yang menyebabkan terjadi penurunan suhu temperatur.

\section{Hasil pengamatan visual dengan kamera thermal}

Berdasarkan hasil visual perbedaan variasi kadar dengan pemanasan didalam mikrowave yang berlangsung selama 60 detik dapat dilihat dengan menggunakan alat kamera thermal seperti ditunjukan pada Gambar 2. 


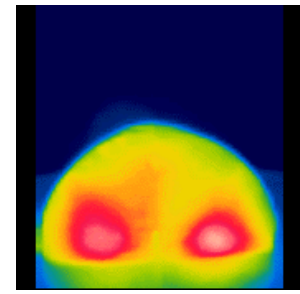

(a)

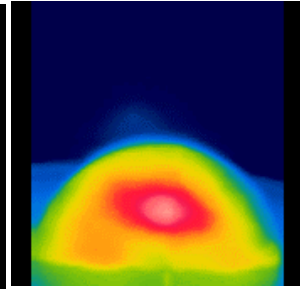

(b)

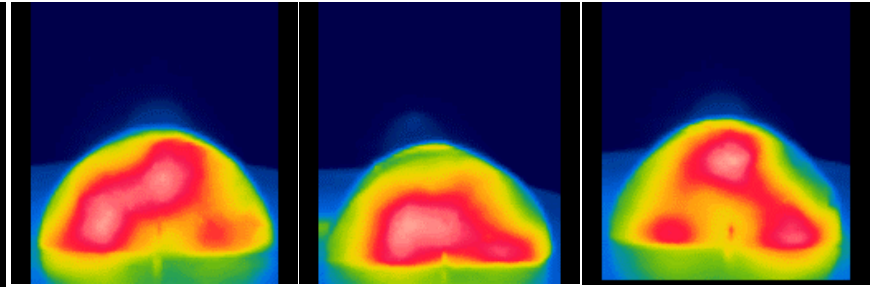

(c) (d)

(e)

Gambar 2. Hasil foto kamera thermal dengan pemanasan durasi 60 detik pada variasi bubutan baja (a) $0 \%$, (b) $0,25 \%$, (c) $0,5 \%$, (d) $0,75 \%$, (e) $1 \%$

Pada Gambar 2, dapat dilihat bahwa campuran variasi kadar bubutan baja yang lebih tinggi umumnya memiliki suhu permukaan yang lebih tinggi (warna merah dan putih menunjukkan suhu paling tinggi) dibandingkan dengan variasi kadar dibawahnya, tetapi pada sampel dengan kadar bubutan baja 1\% suhu permukaan lebih rendah dibandingkan dengan kadar bubutan baja $0,75 \%$. Hal ini terjadi karena pendistribusian bahan tambah bubutan baja yang tidak merata atau buruk pada campuran sampel dengan kadar bubutan baja $1 \%$ sehingga menyebabkan penumpukan bubutan baja di titik tertentu.

\section{Rasio healing pada campuran dengan berbagai kadar limbah bubutan baja}

Hasil pengujian self healing pada berbagai kadar campuran bubutan baja dengan variasi waktu 20 detik, 40 detik, dan 60 detik disajikan dalam Gambar 3-7.

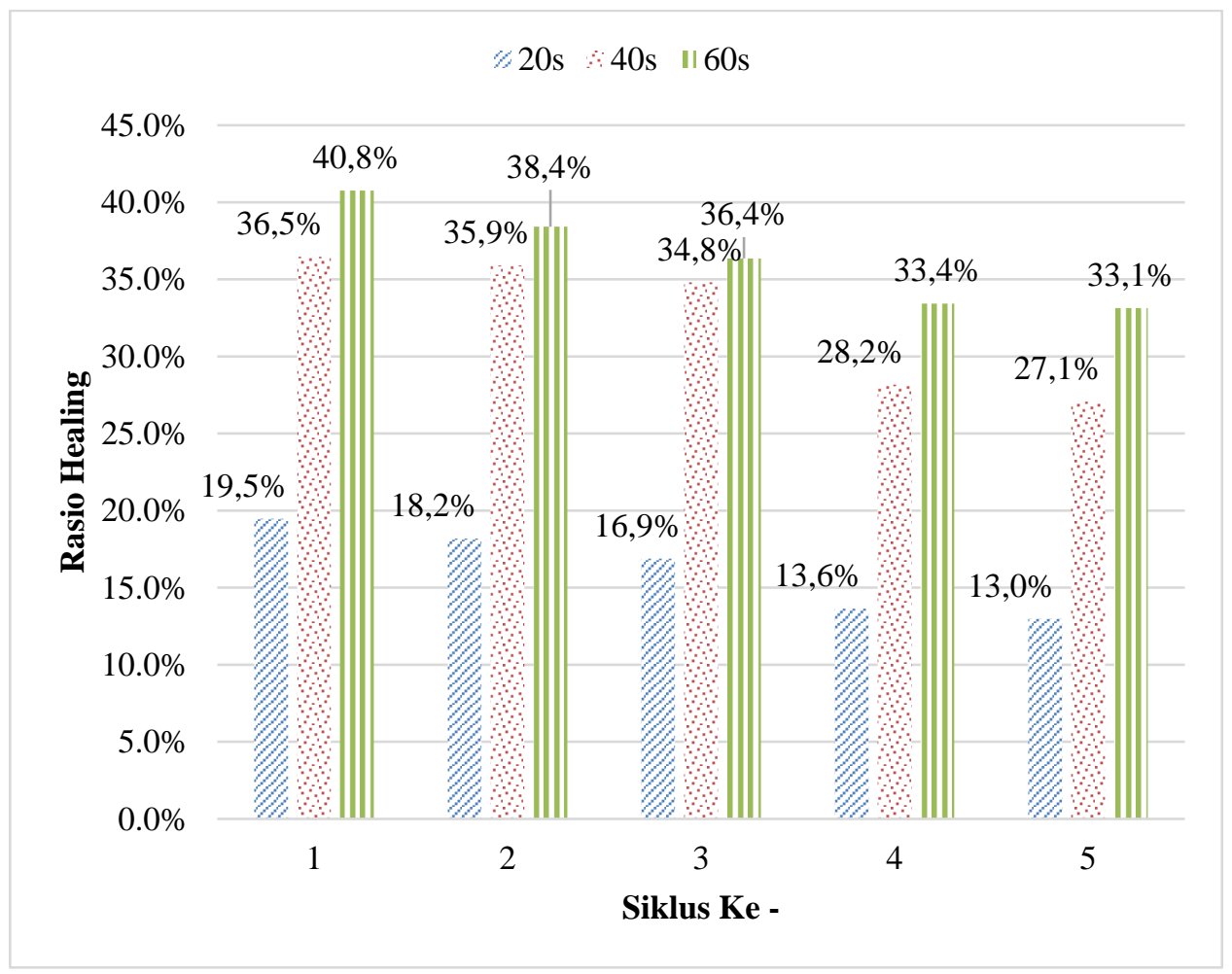

Gambar 3. Grafik self healing pada kadar bubutan baja $0 \%$ 


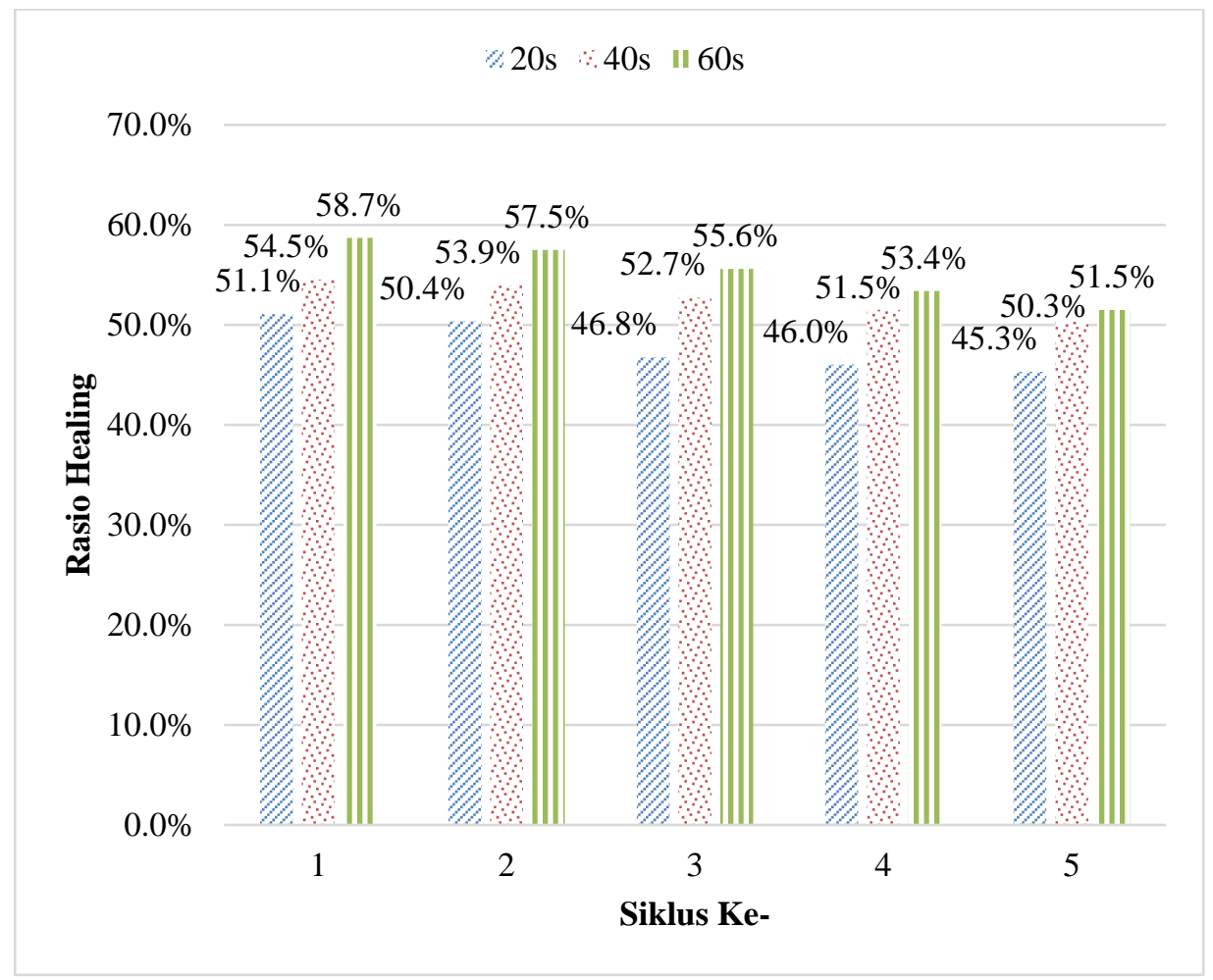

Gambar 4. Grafik self healing pada kadar bubutan baja $0,25 \%$

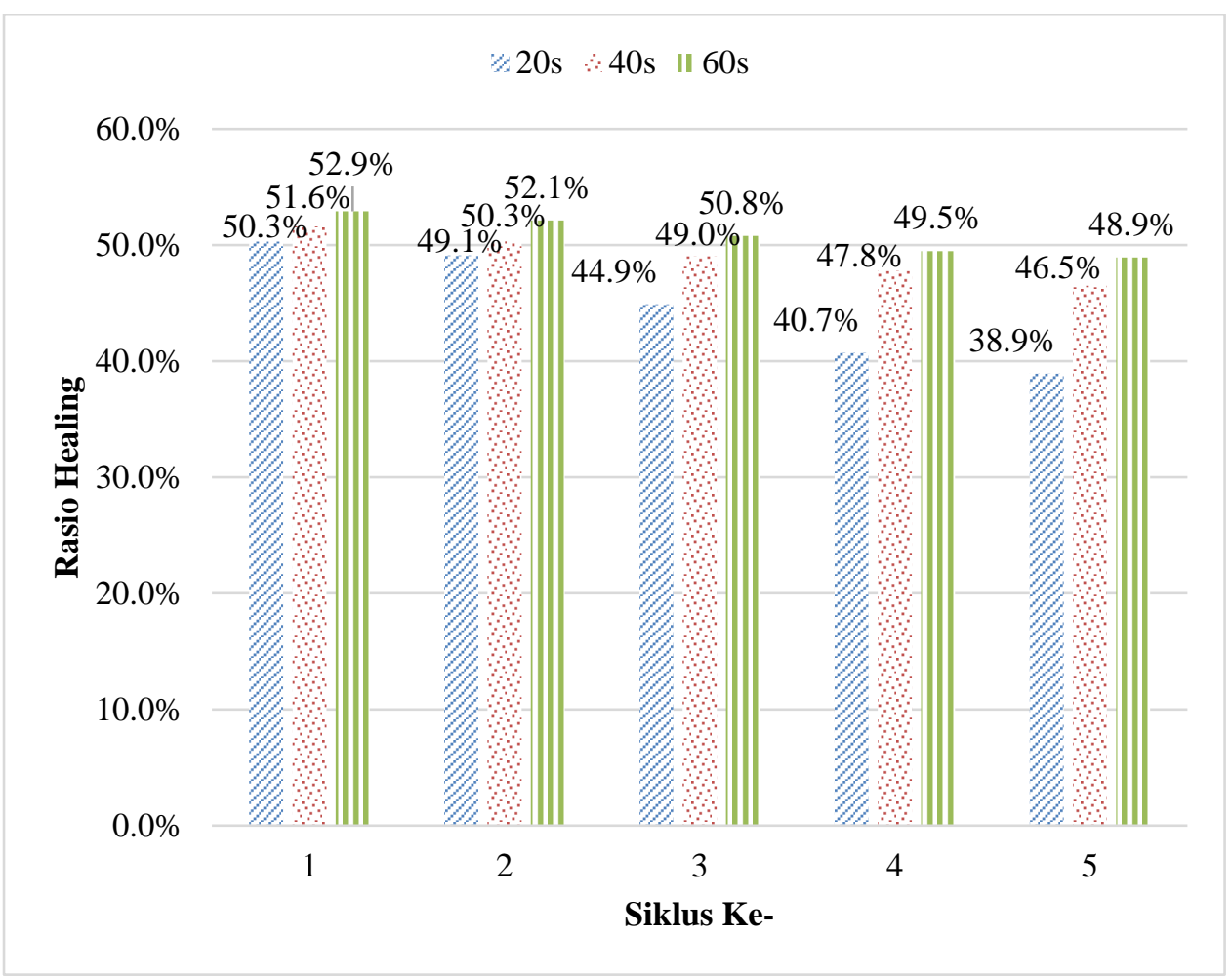

Gambar 5. Grafik self healing pada kadar bubutan baja $0,5 \%$ 


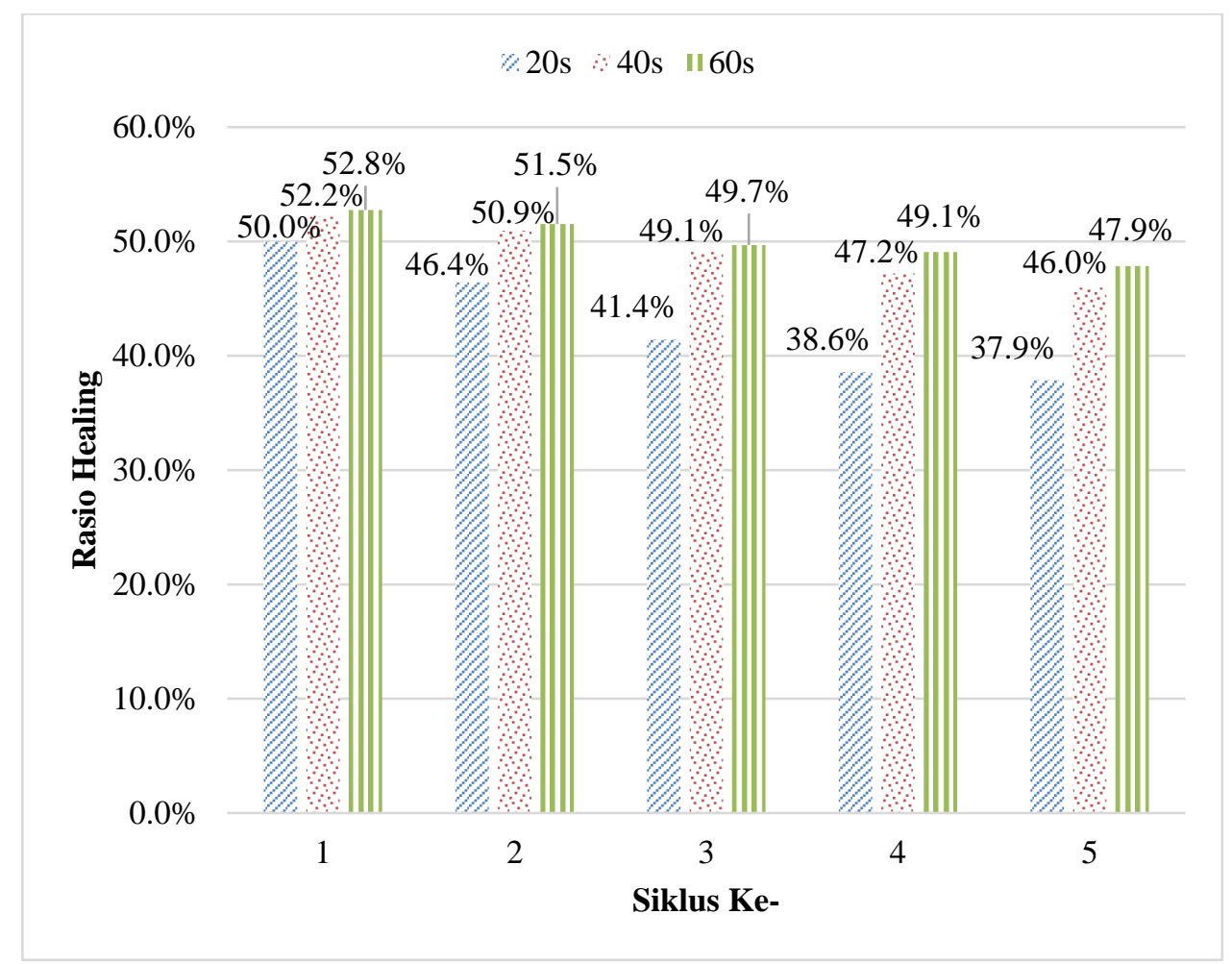

Gambar 6. Grafik self healing pada kadar bubutan baja 0,75\%

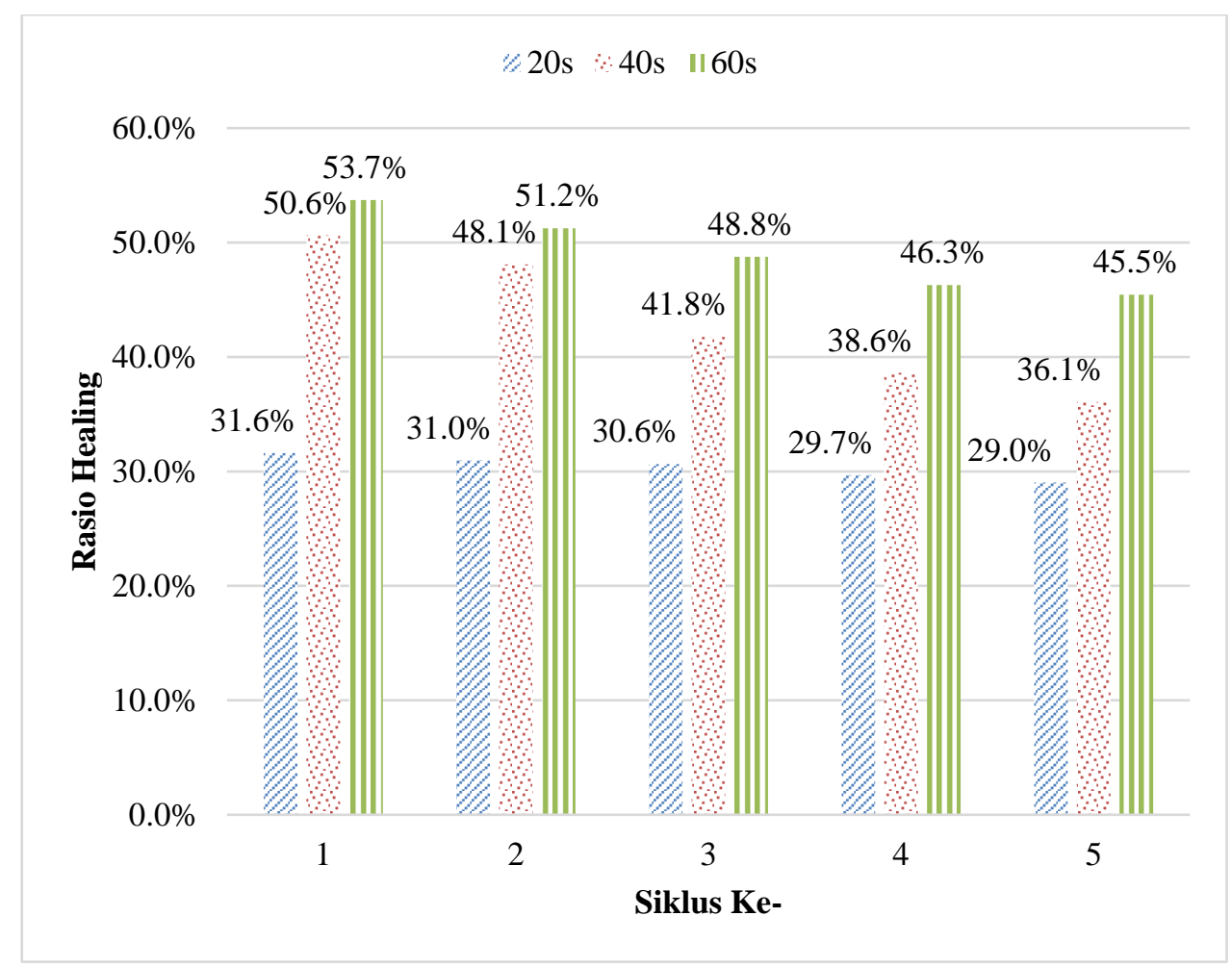

Gambar 7. Grafik self healing pada kadar bubutan baja $1 \%$

Pada semua waktu pemanasan yang dilakukan rasio healing akan berkurang, hal ini terjadi karena benda uji mengalami keretakkan berkali-kali sehingga proses pemanasan tidak bisa 100\% kembali meskipun aspal masih tetap bisa melakukan self healing tanpa terdapat campuran bahan penghantar panas didalamnya. 
Seperti yang dapat dilihat pada Gambar 3, pada siklus pertama kadar baja 0\% dengan pemanasan 60 detik nilai rasio healing mencapai angka 40,8\% selanjutnya pada siklus kedua dengan pemanasan 60 detik rasio healing hannya mencapai angka 38,4\% kemudian pada siklus ketiga, keempat, kelima rasio healing mencapai $(36,4 \%, 33,4 \%, 33,1 \%)$.

Berdasarkan Gambar 4, campuran bubutan baja dengan kadar 0,25\% dari lamanya waktu pemanasan yang terjadi antara 20 detik, 40 detik, dan 60 detik mengalami peningkatan nilai healing ratio rata-rata sebesar 3,4\% pada siklus pertama dengan waktu pemanasan 20 detik sampai waktu pemanasan 40 detik. Kemudian pada waktu pemanasan 40 detik menuju waktu pemanasan 60 detik nilai rasio healing meningkat dengan rata-rata sebesar 4,2\%, hal ini disebabkan karena penambahan durasi pemanasan pada setiap variasi kadar akan meningkatkan nilai rasio healing dan pada durasi yang lebih tinggi panas permukaan akan lebih merata sehingga kemampuan self healing yang terjadi akan lebih baik

Kemudian dapat dilihat pada Gambar 5 Penurunan nilai rasio healing campuran bubutan baja pada siklus kedua sampai dengan siklus kelima dengan waktu pemanasan 40 detik dan 60 detik mengalami penurunan yang lebih stabil dengan nilai rata-rata penurunan rasio healing sebesar (1,2\% dan 2\%), sedangkan pada waktu pemanasan 20 detik stabilnya penurunan healing ratio mulai terjadi pada siklus ketiga sampai dengan siklus kelima dengan nilai penurunan ratarata rasio healing sebesar $0,75 \%$

Berdasarkan Gambar 5 pada semua waktu pemanasan yang dilakukan healing ratio akan berkurang, pada siklus pertama dengan waktu pemanasan 20 detik nilai rasio healing sebesar 50,3\% kemudian pada siklus kedua dengan waktu pemanasan 20 detik nilai rasio healing menjadi 49,1\%, maka nilai penurunan yang terjadi dari siklus kesatu menuju siklus kedua sebesar $1,2 \%$. Selanjutnya penurunan pada siklus kedua menuju siklus ketiga, siklus ketiga menuju siklus keempat, dan siklus keempat menuju siklus kelima sebesar $(4,2 \%, 4,2 \%, 1,8 \%)$.

Kemudian penurunan juga terjadi pada waktu pemanasan 40 detik dan 60 detik, penurunan healing ratio terjadi disetiap siklusnya berawal dari siklus pertama hingga pada siklus kelima. Nilai rata-rata penurunan rasio healing pada waktu pemanasan 40 detik disetiap siklusnya sebesar 1,3\% dan nilai rata-rata penurunan rasio healing pada waktu pemanasan 60 detik sebesar $0,6 \%$ sampai dengan $1,3 \%$.

Berdasarkan pada Gambar 6 Dengan kadar campuran bubutan baja 0,75\% didapat nilai rasio healing tertinggi pada setiap siklus terjadi pada waktu pemanasan 60 detik dilanjutkan dengan 40 detik dan 20 detik. Pada waktu pemanasan 60 detik dan 40 detik penurunan nilai rasio healing dari siklus pertama sampai dengan siklus kelima berkisar antara 4,9\% sampai dengan $6,2 \%$. Sedangkan pada waktu pemanasan 20 detik dengan nilai penurunan rasio healing pada siklus pertama sampai dengan siklus kelima sebesar $12,1 \%$, sehingga banyaknya kadar tambahan bubutan baja yang dicampurkan tidak menjadikan kemampuan self healing asphalt meningkat, maka sebaliknya semakin tinggi penambahan bubutan baja healing ratio semakin kecil.

Dapat dilihat pada Gambar 7 Perbedaan rasio healing terhadap waktu pemanasan 40 detik dan 20 detik pada siklus pertama sebesar $18 \%$ dan perbedaan healing ratio pada waktu pemanasan 60 detik dan 40 detik di siklus pertama sebesar 3,1\%, sehingga banyaknya kadar tambahan pada suatu campuran aspal tidak selalu meningkatkan healing ratio pada sampel, ketika waktu pemanasan yang terjadi terlalu singkat. Sedangkan pada waktu pemanasan 40 detik dan 60 detik kemampuan aspal dalam melakukan self healing jauh lebih baik akibat dari lamanya waktu pemanasan yang terjadi.

Dapat dilihat secara umum variasi kadar bubutan baja yang digunakan untuk bahan tambah campuran sebesar $0 \%$, 0,25\%, 0,5\%, 0,75\%, dan 1\% dari Gambar 3 sampai dengan Gambar 7, bahwa semakin tinggi rasio healing yang didapat, maka akan dipengaruhi oleh lamanya waktu pemanasan dalam mikrowave. Dengan berbagai durasi yaitu 20 detik, 40 detik, dan 60 detik. Sebaliknya semakin sebentar waktu pemanasan dalam mikrowave akan menghasilkan rasio healing yang lebih rendah.

\section{Rasio healing campuran dengan berbagai durasi pemanasan}

Dari hasil analisis self healing yang telah dilaksanakan, dapat dilihat variasi sampel data self healing dengan kadar campuran bahan tambah bubutan baja yang bervariasi, bubutan baja yang dipakai pada penelitian ini adalah $0 \%$, $0,25 \%, 0,5 \%, 0,75 \%$, dan $1 \%$, dengan pemanasan yang dilakukan didalam mikrowave selama 20 detik, 40 detik, dan 60 detik pada Gambar 8-10. 


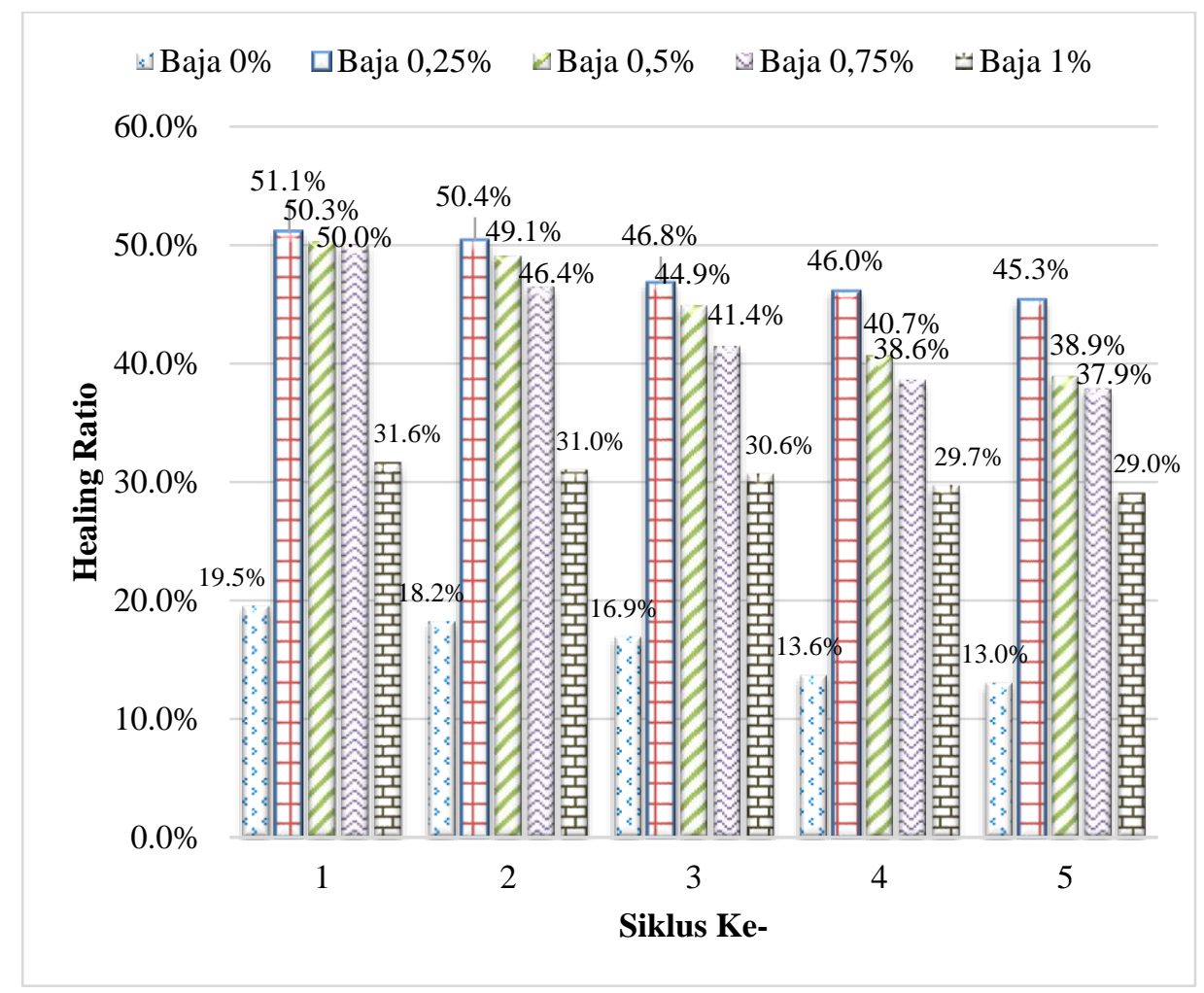

Gambar 8. Grafik data self healing durasi 20 detik dengan semua variasi kadar

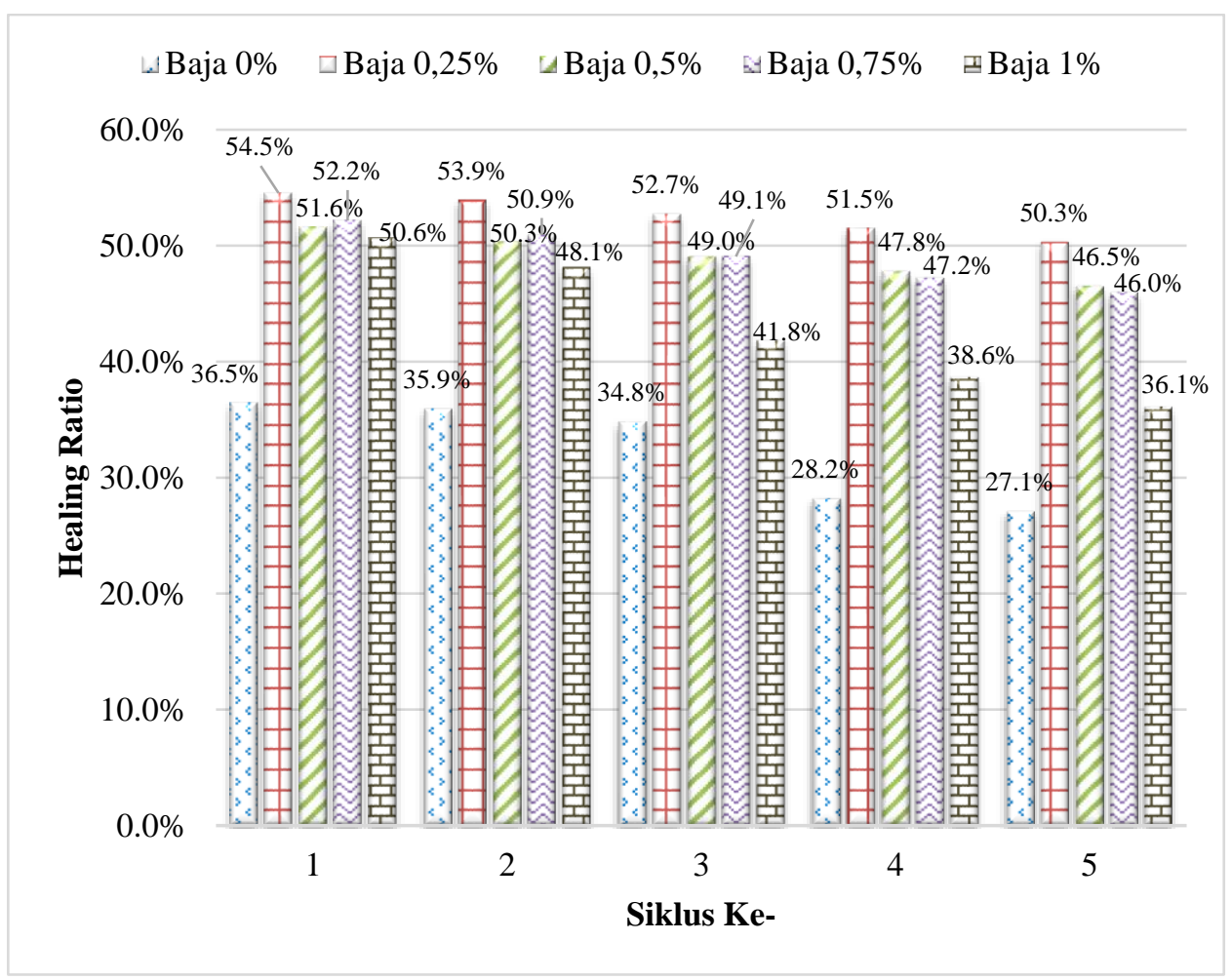

Gambar 9. Grafik data self healing durasi 40 detik dengan semua variasi kadar 


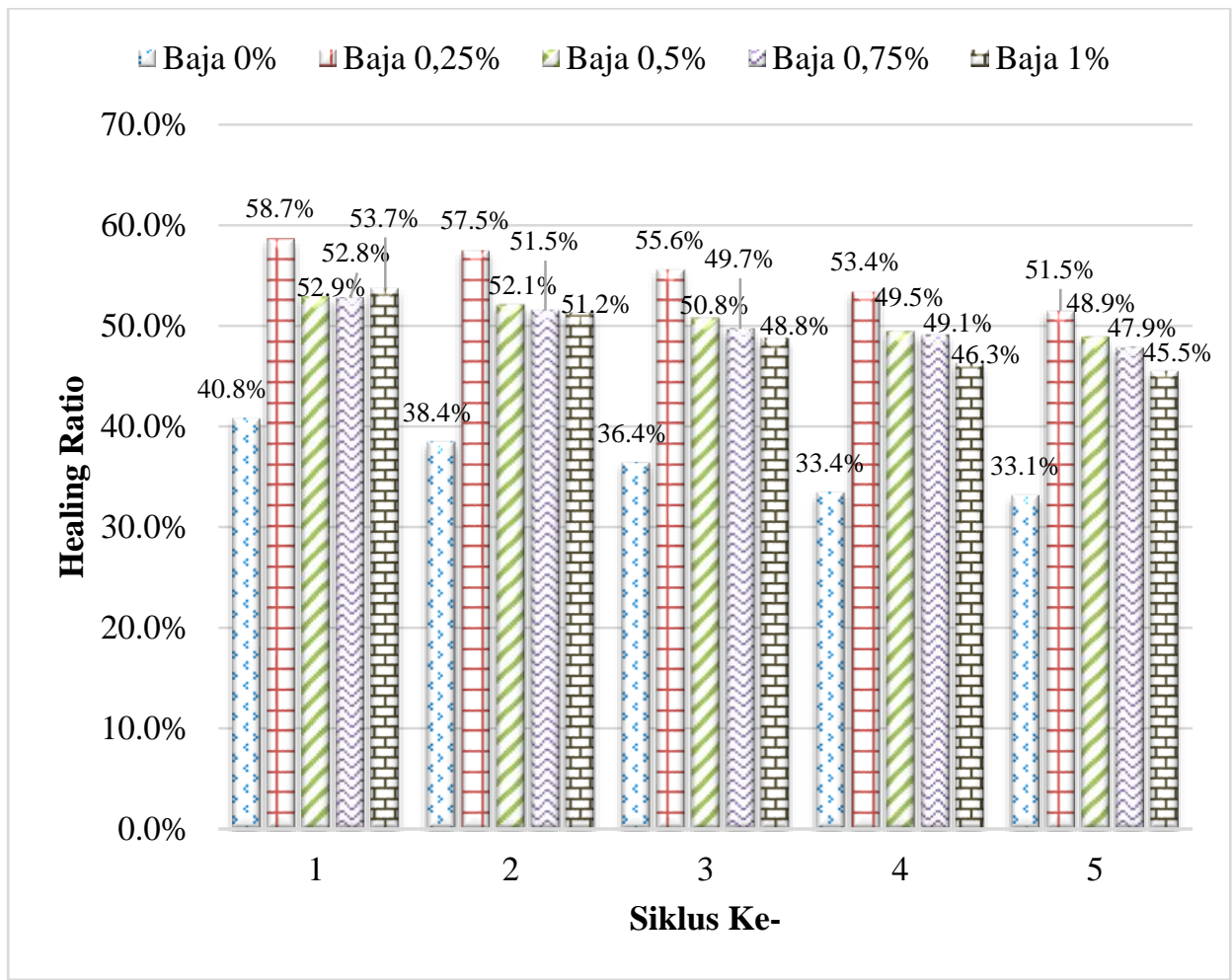

Gambar 10. Grafik data self healing durasi 60 detik dengan semua variasi kadar

Berdasarkan Gambar 8-10, urutan nilai healing ratio pada campuran kadar bubutan baja tertinggi adalah 0,25\%, 0,5\%, $0,75 \%, 1 \%, 0 \%$.

Pada Gambar 8, semakin banyak kadar bubutan baja yang digunakan semakin kecil kekuatan aspal dalam test self healing, dan rasio healing yang terjadi akan semakin kecil. Penurunan rasio healing pada kadar bubutan baja $0,25 \%$ lebih baik dibandingkan pada kadar variasi campuran 0,5\%, 0,75\%, 1\%, 0\%. Hal ini disebabkan semakin bertambahnya kadar campuran bubutan baja dapat merubah komponen struktur yang ada seperti berubahnya rongga udara atau ikatan antar aggregat yang mana hal tersebut merupakan kekuatan dari AC-WC. Berubahnya susunanan juga dapat meningkatkan terjadinya cluster pada campuran aspal yang mengakibatkan kerusakan pada agregat sehingga dapat menurunkan kemampuan self healing pada aspal. Penurunan pada siklus pertama ke siklus kedua dengan kadar campuran bubutan baja $0,25 \%$ sebesar $0,7 \%$, kemudian pada siklus kedua ke siklus ketiga nilai penurunan rata-rata rasio healing yang terjadi sebesar 3,6\%, selanjutnya pada siklus ketiga menuju siklus keempat penurunan rasio healing sebesar $0,8 \%$, dan pada siklus yang terakhir nilai rata-rata penurunan rasio healing sebesar $0,7 \%$, didapat pada siklus kelima nilai rasio healing sebesar 45,3\% pada kadar campuran bubutan baja 0,25\%

Berdasarkan Gambar 9, walaupun saat siklus pertama sampai dengan siklus ketiga nilai rasio healing pada kadar $0,75 \%$ sebesar $52,2 \%, 50,9 \%, 49,1 \%$ dan berada pada urutan kedua tetapi pada siklus-siklusnya selanjutnya rasio healing cenderung menurun menjadi 47,2\%, dan 46,0\% dan berada dibawah kadar campuran bubutan baja $0,5 \%$ dengan nilai rasio healing pada siklus keempat dan kelima sebesar 47,8\% dan 46,5\% ini disebabkan penambahan kadar bahan tambah bubutan baja yang semakin tinggi tidak selalu memberikan penurunan rasio healing yang baik pada setiap siklus, akibat dari ketidakseuaian kadar campuran bisa jadi menurunkan kualitasnya pada setiap siklussiklus selanjutnya.

Dari hasil Gambar 10 menunjukkan pada pemanasan 60 detik rasio healing cenderung menurun disetiap siklusnya. Hal ini disebabkan semakin bertambahnya kadar campuran bubutan baja dapat merubah komponen struktur yang ada seperti berubahnya rongga udara atau ikatan antar agregat yang mana hal tersebut merupakan kekuatan dari AC-WC. Berubahnya susunanan juga dapat meningkatkan terjadinya cluster pada campuran aspal yang mengakibatkan kerusakan pada agregat sehingga dapat menurunkan kemampuan self healing pada aspal. Kemudian benda uji yang mengalami keretakkan berkali-kali juga dapat mempengaruhi turunnya kemampuan self healing pada setiap siklus meskipun aspal dapat melakukan self healing pada saat terjadi retakan tetapi tidak dapat mengembalikan kemampuan aspal 100\% seperti semula sehingga proses pemanasan tidak bisa $100 \%$ kembali pada siklus pertama meskipun aspal masih tetap bisa melakukan self healing pada setiap siklusnya. Dan nilai healing ratio rata-rata dengan kadar campuran $0,25 \%, 0,5 \%, 0,75 \%, 1 \%$, dan $0 \%$ sebesar $55,34 \%, 50,72 \%, 50,2 \%, 49,1 \%, 36,42 \%$. 


\section{Hasil pengamatan visual terhadap proses self healing}

Pada penelitian ini pengamatan visual self healing dilakukan yang bertujuan untuk melihat kemampuan self healing pada sampel dengan variasi durasi pemanasan yang berbeda, yang telah disajikan pada Gambar 11.
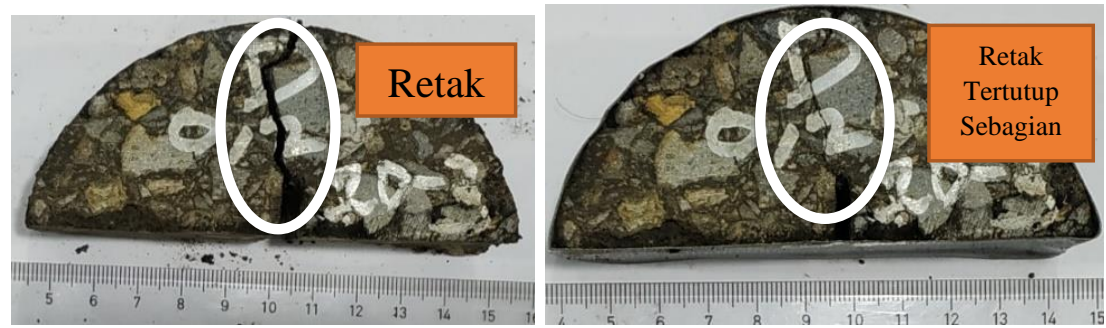

(a)
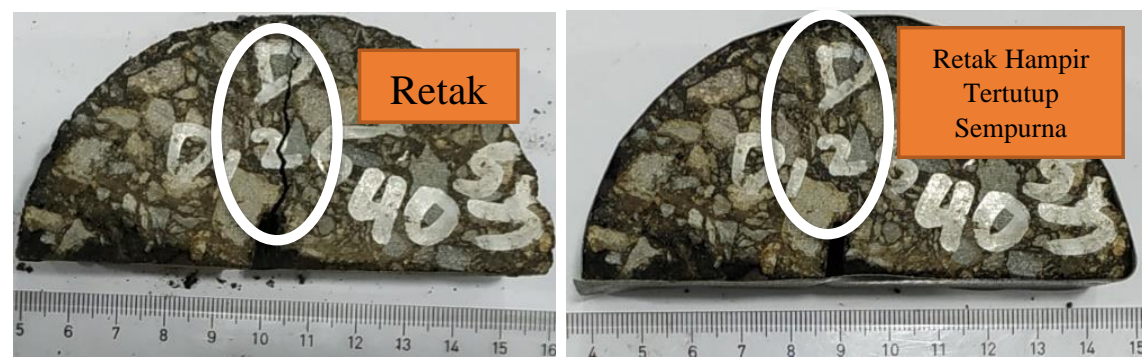

(b)
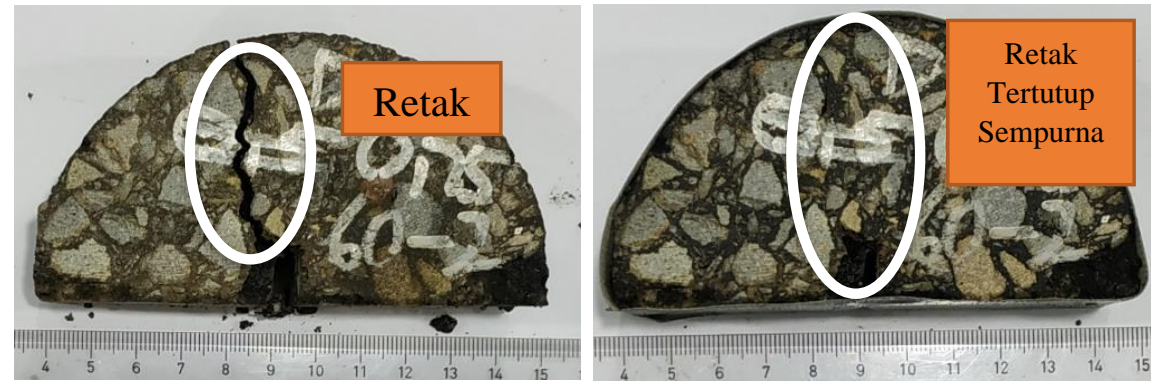

(c)

Gambar 11. Sebelum dan sesudah crack healing berdasarkan lama pemanasan (a) 20 detik, (b) 40 detik, dan (c) 60 detik

Berdasarkan Gambar 11, dapat dilihat kemampuan sampel dalam melakukan self healing ketika sedang terjadi retakan menjadi rapat sempurna atau sebagian rapat sempurna. Hal ini karena lamanya detik dalam pemanasan mikrowave. Semakin lama pemanasan mikrowave maka retakan yang terjadi akan rapat sempurna. Sebaliknya semakin cepat pemanasan dalam mikrowave maka sebagian retakan saja yang akan menyatu dengan sempurna. Dapat dilihat pada durasi pemanasan 20 detik sampel sudah dapat melakukan sefl healing, tetapi kemampuan self healing yang terjadi hanya sebagian saja dan masih terdapat celah keretakan yang yang terjadi pada sampel. Sedangkan pada waktu pemasanan 40 detik celah sudah mulai tertutup dan sedikit keretakan yang terlihat, kemudian pada durasi pemanasan 60 detik self healing yang terjadi sudah sempurna dan retakan yang terjadi telah diperbaiki dengan sempurna.

\section{KESIMPULAN}

Berdasarkan hasil pembahasan pada penelitian uji self healing dan karakteristik temperatur, dapat ditarik beberapa kesimpulan sebagai berikut:

1. Penambahan campuran limbah bubutan baja dapat digunakan karena meningkatkan potensi self healing dilihat dari rasio healing yang didapatkan

2. Pada kadar campuran bubutan baja $0 \%$ terbukti sampel dapat melakukan self healing tetapi hasil yang didapatkan tidak sebaik ketika menggunakan variasi bahan tambah campuran serat baja 0,25\%,0,5\%,0,75\% dan $1 \%$. Karena tidak terdapat bahan yang dapat membantu menghantarkan panas pada aspal. 
3. Pengujian dengan menggunakan kamera thermal didapatkan suhu maksimum terdapat pada variasi kadar campuran bubutan baja 0,75\% dengan waktu pemanasan selama 20 detik, 40 detik, dan 60 detik. Pada waktu 20 detik suhu mencapai $62,6^{\circ} \mathrm{C}$, waktu 40 detik suhu mencapai $85,4^{\circ} \mathrm{C}$, dan waktu 60 detik suhu mencapai $105^{\circ} \mathrm{C}$.

4. Persentasi healing ratio menurun seiring dengan penambahan kadar bubutan baja dalam campuran AC-WC. Nilai healing ratio pada kadar bubutan baja $0 \%$ dalam waktu pemanasan 20 detik di siklus kelima yaitu sebesar $13,0 \%$, untuk kadar serat baja 0,25\% sebesar 45,3\%, untuk kadar bubutan baja 0,5\% sebesar 38,9\%, untuk kadar bubutan baja $0,75 \%$ sebesar $37,9 \%$, dan pada kadar bubutan baja $1 \%$ dengan nilai $29 \%$.

5. Penambahan campuran limbah bubutan baja dapat digunakan karena telah memenuhi syarat dari ketentuan yang ditetapkan seperti dari aspek teknis, aspek ekonomi, dan aspek lingkungan.

\section{DAFTAR PUSTAKA}

Ajam, H., Gómez-Meijide, B., Artamendi, I., \& Garcia, A. (2018). Mechanical and healing properties of asphalt mixes reinforced with different types of waste and commercial metal particles. Journal of Cleaner Production, 192, 138-150.

Cao, X., Wang, H., Cao, X., Sun, W., Zhu, H., \& Tang, B. (2018). Investigation of rheological and chemical properties asphalt binder rejuvenated with waste vegetable oil. Construction and Building Materials, 180, 455-463.

Garc'1a, A., Norambuena-Contreras, J., Bueno, M., \& Partl, M. N. (2014). Influence of Steel Wool Fibers on the Mechanical, Termal, and Healing Properties of Dense Asphalt Concrete. Journal of Testing and Evaluation, 42(5), 1107-1118.

Garcia, A., Schlangen, E., \& Van de Ven, M. (2009). Two Ways of Closing Cracks on Asphalt Concrete Pavements: Microcapsules and Induction Heating. Key Engineering Materials, 573-576. doi:https://doi.org/10.4028/www.scientific.net/kem.417-418.573

González, A., Norambuena-Contreras, J., Storey, L., \& Schlangen, E. (2018). Self-healing properties of recycled asphalt mixtures containing metal waste: An approach through microwave radiation heating. Journal of environmental management, 214, 242-251.

Li, H., Dong, B., Wang, W., Zhao, G., Guo, P., \& Ma, Q. (2019). Effect of Waste Engine Oil and Waste Cooking Oil on Performance Improvement of Aged Asphalt. Applied Sciences, 9(9), 1767. doi:https://doi.org/10.3390/app9091767

Liu, Q., Chen, C., Li, B., Sun, Y., \& Li, H. (2018). Heating characteristics and induced healing efficiencies of asphalt mixture via induction and microwave heating. Materials, 11(6), 913.

Pemerintah Republik Indonesia. (1999). PERATURAN PEMERINTAH REPUBLIK INDONESIA NOMOR 18 TAHUN 1999 TENTANG PENGELOLAAN LIMBAH BAHAN BERBAHAYA DAN BERACUN. Jakarta: Pemerintah Republik Indonesia.

Pérez, I., Agzenai, Y., Pozuelo, J., Sanz, J., Baselga, J., García, A., \& Pérez, V. (2016). Self-healing of asphalt mixes, containing conductive modified bitumen, using microwave heating. Proceedings of the 6th Eurasphalt \& Eurobitume Congress, (pp. 1-3). Prague.

Sun, Y. H., Liu, Q. T., Wu, S. P., \& Shang, F. (2014). Microwave heating of steel slag asphalt mixture. Key Engineering Materials, 599, 193-197.

Tajudin, A. N., \& Suparma, L. B. (2017). Pengaruh Rendaman pada Indirect Tensile Strength Campuran AC-BC dengan Limbah Plastik sebagai Agregat Pengganti. MEDIA KOMUNIKASI TEKNIK SIPIL, 23(2), $166-173$. doi:https://doi.org/10.14710/mkts.v23i2.16128

White, S. R., Sottos, N. R., Guebelle, P. H., Moore, J. S., Kessler, M. R., Sriram, S. R., . . Viswanathan, S. (2001). Autonomic healing of polymer composites. Nature, 409(6822), 794-797. 